\title{
О МЕЖДУНАРОДНОЙ НАУЧНО-ПРАКТИЧЕСКОЙ КОНФЕРЕНЦИИ, ПОСВЯЩЕННОЙ ИЗУЧЕНИЮ БОТАЯ
}

\author{
(c) 2019 г. Б.Б. Бесетаев
}

В рамках международной конференции обсуждались основные итоги по междисциплинарным исследованиям энеолитического памятника Ботай. В работе конференции приняли участие представители науки, культуры, ведущие ученые Казахстана, а также стран ближнего и дальнего зарубежья. На конференции рассматривались проблемы становления коневодческой культуры на территории Центральной Азии. Наибольшее внимание привлекло выступление, посвященное генетическим исследованиям костных останков, где рассматривались вопросы культурогенеза и культурной пренадлежности памятников. Обсуждались древние миграционные процессы в контексте конно-транспортной коммуникации, и природно-климатических факторов, которые, безусловно, влияли на динамическое развитие культурного арела в целом. По результатам конференции было принято решение о дальнейшем изучении энеолитических памятников с привлечением междисциплинарных методов.

Ключевые слова: археология, Центральная Азия, степная цивилизация, археологические изучения, энеолитические памятники, ботайская культура

С целью реализации задач программной статьи первого президента РК Н.А. Назарбаева «Семь граней великой степи» в рамках VI международных Фарабиевских чтений 4-6 апреля 2019 года в г. Алматы была проведена международная научно-практическая конференция «Ботайская культура и другие энеолитические памятники Центральной Азии», организованная научноисследовательским институтом «Археология и степные цивилизации» факультета истории, археологии и этнологии при Казахском национальном университете имени альФараби.

Цель конференции - обсуждение основных итогов многолетних исследований ботайских памятников в контексте коневодческих культур степной цивилизации, в котором приняли участие более 70 специалистов: археологи, этнографы, генетики, биологи, географы, культурологи из Казахстана, а также стран ближнего и дальнего зарубежья (Великобритании, Германии, Китая, Литвы, России, Франции).

На конференции выступили с докладами директор НИИ «Институт археологии и степных цивилизаций» Казахского национального университета имени аль-Фараби, член-корреспондент Германского археологического института В.Ф. Зайберт, доктор биологических наук, профессор Евразийского национального университета имени Л.Н. Гумилева М.Ж. Нурушев, директор центра 


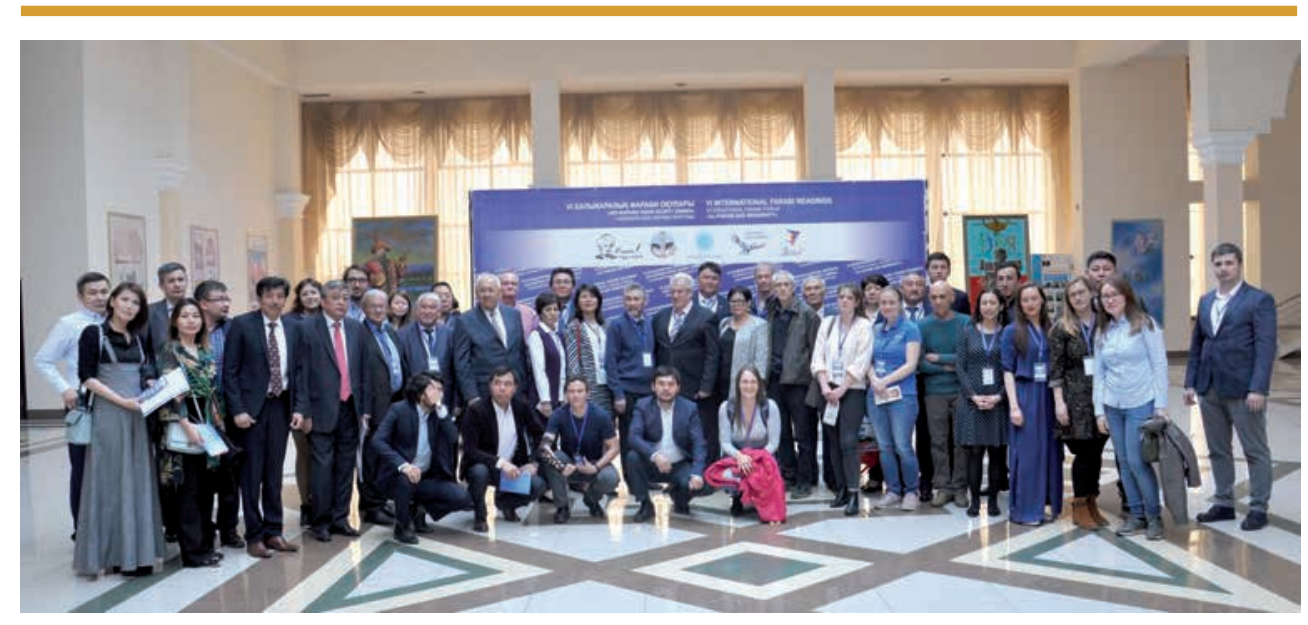

Участники международной научно-практической конференции «Ботайская культура и другие энеолитические памятники Центральной Азии». Фото Б. Рысбек

Participants of the international scientific and practical conference «Botay culture and other Eneolithic monuments of Central Asia». Photo by B. Rysbek

«Человек - животное - окружающая среда» при Эксетерском университете, профессор археологии Алан Оутрам, Сара Баракат, Алекс Прайop; Айви Джей. Оуэнс, Элина Ананьевская из Вильнюсского университета; Минь Ран, Жаодонг Фэнг - из Хэнаньского университета, Чунгвон Чжон, Имель А., Краузе Ж. - из Института науки о человеческой истории им. Макса Планка и др.

На конференции рассматривались теоретические и методологические аспекты археологии на современном этапе. В том числе обсуждалась возможность дальнейшего сотрудничества в области междисциплинарных исследований археологических памятников. Междисциплинарные исследования специалистов из разных сфер, в частности, генетиков, зооморфологов, остеологов позволили применить новые научные методы, такие как изотопный анализ, анализ липидных и протеомных остатков, датирование AMS, геофизические и геохимические исследования, архео- ботанику и микроморфологию почвы, а также новые подходы к зооархеологии. Новые инновационные методы в исследованиях эпохи энеолита Казахстана, расширили информацию о характере и насыщенности культурного слоя в различных зонах уникального по масштабам поселения с его специфическими остатками человеческой деятельности и животных. Итоги многолетних международных исследований Ботая (IV-III тыс. до н.э.) показали, что впервые лошадь была одомашнена именно на территории Казахстана, а пассионарный степной всадник открыл новую эру коннотранспортной коммуникации, которую совершенствовал и распространял по всему Свету на протяжении многих столетий.

По итогам конференции принята резолюция дальнейшего изучения энеолитических культур Казахстана в целом, подписаны меморандумы о сотрудничестве в сфере подготовки молодых ученых, по проведению совместных исследований. 
Бесетаев Б.Б. О международной научно-практической конференции, посвященной изучению Ботая

В рамках конференции была организована выставка из археологической коллекции Центрального государственного музея РК «Материалы Северо-Казахстанско-Кокшетауской археологической экспедиции 20052006 годов под руководством доктора исторических наук В.Ф. Зайберта».

Натретий день был организован выезд в Государственный историкокультурный музей-заповедник «Иссык», где участники конференции ознакомились с одной из известнейших находок казахстанских археоло- гов - «Золотым человеком», и элитарными курганами сакской эпохи.

Стоить отметить, что для современного казахстанского общества, прежде всего, нужны прикладные программы историко-культурного, этнокультурного и патриотического воспитания граждан. Сегодня это могут быть музейно археологические и этнографические комплексы под открытым небом, где наглядными привлекательными инновационными методами демонстрируется уникальная история нашей страны.

\section{Сведения об авторе:}

Бесетаев Бауыржан Берканович - магистр археологии и этнологии, старший преподаватель, кафедра археологии, этнологии и музеологии, КазНУ им. аль-Фараби (г. Алматы, Казахстан); besetaev86@mail.ru

\section{БОТАЙ ЕСКЕРТКІШТЕРІНДЕГІ ЗЕРТТЕУЛЕРГЕ АРНАЛҒАН ХАЛЫҚАРАЛЫҚ ҒЫЛЫМИ-ТӘЖІРИБЕЛІК КОНФЕРЕНЦИЯ ЖАЙЫНДА}

\section{Б.Б. Бесетаев}

Халықаралық конференцияның жұмысы барысында энеолит кезеңімен мерзімделетін Ботай ескерткіштеріне жүргізілген пәнаралық зерттеулердің негізгі қорытындылары талқыланды. Конференция жұмысына түрлі ғылым, мәдениет саласындағы алыс және жақын шетелдердің жетекші ғалымдары қатысты. Конференцияның негізгі бағыттарының бірі - Орталық Азия аумағындағы жылқыны алғаш қолға үйрету мәселелері қарастырылды. Баяндамалардың ішінде сүйек қалдықтары арқылы зерттеулер аясында мәденигенез және ескерткіштердің мәдени негіздері тұрғысында сараптамалардың қорытындылары туралы генетика саласының жұмыстарын айрықша атап өтуге болады. Сонымен қатар, мәдени шекаралардың динамикалық дамуы мен кеңеюінде ерекше орын алатын ежелгі көші-қон үдерістеріне әсер еткен жылқыны қолға үйретумен қатар, табиғи-климаттық факторлар да талқыланды. Конференцияның қорытындысында энеолиттік ескерткіштерді пәнаралық зерттеулер әдістері арқылы ары қарай зерттеудің маңызы жоғары екендігі айтылды.

Түйін сөздер: археология, Орталық Азия, далалық өркениет, археологиялық зерттеулер, энеолиттік ескерткіштер, ботай мәдениеті

\section{ABOUT INTERNATIONAL SCIENTIFIC PRACTICAL CONFERENCE DEDICATED TO THE STUDY OF BOTAY}

\section{B.B. Besetayev}

The main results of interdisciplinary studies on the Eneolithic site Botay were discussed at the international conference. The conference was attended by representatives of science, culture, leading scientists from Kazakhstan, as well as from far and near abroad. 
Horse-breeding culture formation problems in the Central Asia were considered at the conference. The most attention was drawn to the presentation about genetic studies of bone remains, where the issues of culture genesis and cultural inheritance of monuments were considered. The ancient migration processes were discussed in the context of horse transport communication and natural-climatic factors that undoubtedly influenced the dynamic development of the cultural area as a whole. According to the conference results, it was decided to further study the Eneolithic sites using interdisciplinary methods.

Keywords: archaeology, Central Asia, steppe civilization, archaeological studies, Eneolithic monuments, Botay culture

\section{About the Author:}

Besetayev Bauyrzhan B. Master of Archeology and Ethnology, Senior Lecturer, Department of Archeology, Ethnology and Museology, Al-Farabi Kazakh National University, Almaty, Kazakhstan; besetaev86@mail.ru 